\title{
Extinction Training Regulates Neuroadaptive Responses to Withdrawal from Chronic Cocaine Self-Administration
}

\author{
David W. Self, ${ }^{1,3}$ Kwang-Ho Choi, ${ }^{1}$ Diana Simmons, ${ }^{1}$ John R. Walker, ${ }^{2}$ \\ and Cynthia S. Smagula ${ }^{1}$ \\ ${ }^{1}$ Department of Psychiatry, The Seay Center for Basic and Applied Research in Psychiatric Illness, University of Texas \\ Southwestern Medical Center, Dallas, Texas 75390-9070 USA; ${ }^{2}$ Genomics Institute of the Novartis Research Foundation, \\ San Diego, California 92121-1125 USA
}

\begin{abstract}
Cocaine produces multiple neuroadaptations with chronic repeated use. Many of these neuroadaptations can be reversed or normalized by extinction training during withdrawal from chronic cocaine self-administration in rats. This article reviews our past and present studies on extinction-induced modulation of the neuroadaptive response to chronic cocaine in the mesolimbic dopamine system, and the role of this modulation in addictive behavior in rats. Extinction training normalizes tyrosine hydroxylase levels in the nucleus accumbens (NAc) shell, an effect that could help ameliorate dysphoria and depression associated with withdrawal from chronic cocaine use. Extinction training also increases levels of GluR1 and GluR2/3 AMPA receptor subunits, while normalizing deficits in NR1 NMDA receptor subunits, in a manner consistent with long-term potentiation of excitatory synapses in the NAc shell. Our results suggest that extinction-induced increases in AMPA and NMDA receptors may restore deficits in cortico-accumbal neurotransmission in the NAc shell and facilitate inhibitory control over cocaine-seeking behavior. Other changes identified by gene expression profiling, including up-regulation in the AMPA receptor aggregating protein Narp, suggest that extinction training induces extensive synaptic reorganization. These studies highlight potential benefits for extinction training procedures in the treatment of drug addiction.
\end{abstract}

Chronic or repeated cocaine administration produces numerous cellular changes in the mesolimbic dopamine system that are thought to contribute to addiction-related changes in drug sensitivity, craving, and mood (Self and Nestler 1998; White and Kalivas 1998; Koob and Le Moal 2001; Nestler 2001). Most changes generally reflect a neuroadaptive response to the unconditioned pharmacological effects of continued and excessive drug administration. However, experiential factors, such as whether the drug is voluntarily or forcibly administered, can play a major role in determining both qualitative and quantitative cellular responses to the drug (Wilson et al. 1994; Dworkin et al. 1995; Hemby et al. 1997; Graziella De Montis et al. 1998; Kuzmin and Johansson 1999; Mark et al. 1999; Porrino et al. 2002).

Experiential factors also could play a pivotal role in modulating neuroadaptive responses during drug withdrawal, although such modulation has only recently been investigated. Here, we review our studies on the effects of repeated extinction training on multiple neuroadaptations in withdrawal from chronic cocaine self-administration. Surprisingly, extinction training reverses many neuroadaptations in cocaine withdrawal, whereas other changes arise as a consequence of extinction training. In some cases, these changes have been functionally related to a reduction in addictive behavior, suggesting a bidirectional interaction between neuroadaptations to chronic drug use and nonreinforced drug-seeking experience that ultimately influences the propensity for relapse (Fig. 1).

Extinction training inhibits conditioned behaviors through learning of new contextual relationships (Bouton 2002). In ani-

\footnotetext{
${ }^{3}$ Corresponding author.
}

E-MAIL david.self@utsouthwestern.edu; FAX (214) 648-4947.

Article and publication are at http://www.learnmem.org/cgi/doi/10.1101/ Im.81404. mals trained to self-administer appetitive rewards, initial exposure to extinction conditions also causes frustrative stress when reward is withheld, as indicated by the release of multiple stressrelated substances including corticosterone and $\beta$-endorphin (Davis et al. 1976; Micco Jr. et al. 1979; Mason 1983; Roth-Deri et al. 2003; Zangen and Shalev 2003). The role of extinction learning- and extinction-related stress in regulating the neuroadaptive response to chronic cocaine self-administration is unknown, but certain activity-related events in animals undergoing extinction suggest that neuroplasticity may contribute to this regulation. Our studies help to establish an initial conceptual framework for guiding future investigations on this topic, and suggest that extinction-induced regulation of the neuroadaptive response to drugs potentially could be useful for treating both behavioral and neurobiological consequences of drug addiction.

\section{RESULTS AND DISCUSSION}

Extinction Training Reverses Cocaine-Induced Deficits in Tyrosine Hydroxylase in the NAc Shell

The mesolimbic dopamine system, consisting of dopamine neurons in the ventral tegmental area (VTA) and projections to the nucleus accumbens (NAc), is a major neural substrate for the reinforcing effects of psychostimulant drugs such as cocaine (Roberts and Koob 1980; Pettit et al. 1984; Zito et al. 1985; Carlezon Jr. et al. 1995; Wise 1998). Cocaine-induced regulation of tyrosine hydroxylase $(\mathrm{TH})$, the rate-limiting enzyme for dopamine synthesis, is well documented in the VTA and dopaminergic terminals of the NAc in studies where cocaine is forcibly administered by repeated bolus intraperitoneal injections (Trulson et al. 1987; Beitner-Johnson and Nestler 1991; Sorg et al. 1993; Vrana et al. 1993; Masserano et al. 1996; Todtenkopf et al. 2000). 


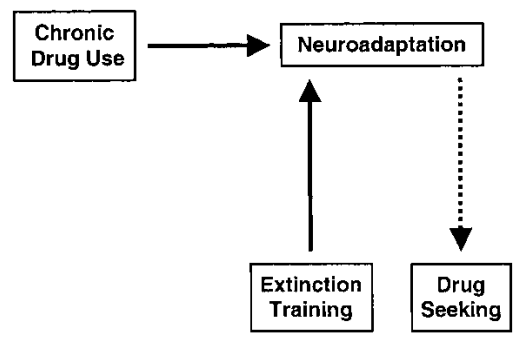

Figure 1 Neuroadaptations to chronic drug exposure are thought to promote addictive behavior, but these changes can be modulated by experiential factors such as repeated exposure to extinction conditions. Our studies suggest that extinction training during withdrawal from chronic cocaine self-administration modifies these neuroadaptations in a manner that may reduce (dotted line) their contribution to drug-seeking behavior.

These studies found that the amount of TH in the NAc increases, decreases, or does not change depending on the cocaine administration regimen and length of withdrawal period.

In our studies, rats are trained to perform a simple leverpress response in order to receive intravenous cocaine injections, and are allowed to self-administer intravenous cocaine in limited daily access sessions (see Materials and Methods). Cocaine selfadministration is conducted in environmentally distinct test chambers, and animals are returned to their home cages between self-administration test sessions. Following self-administration training, some animals are subjected to daily extinction training sessions in the self-administration test chambers (4-6 h/d) over a 1 -wk period during withdrawal from cocaine self-administration, whereas other animals remain in their home cages for the duration of cocaine withdrawal. Brain tissue is collected from animals at various withdrawal time points, either with or without extinction training experience, and at least $12-16 \mathrm{~h}$ after the final extinction training session. NAc core and shell tissue is obtained from punches of coronal brain slices, and analyzed for either mRNA (Northern blot or microarray) or protein levels (Western blot) of $\mathrm{TH}$ and other target proteins.

In each experiment, cocaine-trained groups self-administer similar amounts of cocaine, but differ only in their extinction training experience. Our initial studies found that chronic cocaine self-administration decreased $\mathrm{TH}$ protein levels in the NAc shell (but not core) to $71 \%$ of untreated control levels after $1 \mathrm{wk}$ of withdrawal from self-administration in the animals' home cages (Schmidt et al. 2001). TH levels were not decreased after 1 $\mathrm{d}(12-16 \mathrm{~h})$ of withdrawal, suggesting that regulation is a consequence of a longer withdrawal period rather than cocaine itself. These region-specific deficits in NAc TH levels could underlie a reported tolerance to cocaine-induced dopamine release that occurs in the shell following repeated cocaine administration (Cadoni et al. 2000), whereas a more commonly reported sensitization in the dopamine response to cocaine occurs in the core (e.g., Kalivas and Duffy 1993; Cadoni et al. 2000). We previously found reduced TH levels in the NAc of rats self-administering heroin (Self et al. 1995), and others have found TH deficits in the NAc following chronic ethanol self-administration (Ortiz et al. 1995). Thus, chronic self-administration of a variety of addictive drugs reduces the amount of $\mathrm{TH}$ in the NAc, and could contribute to reduced dopamine synthesis and basal extracellular levels in withdrawal from chronic drug administration (Brock et al. 1990; Pothos et al. 1991; Rossetti et al. 1992; Weiss et al. 1992; Diana et al. 1993).

In contrast, repeated extinction training during the 1-wk withdrawal period completely normalized deficits in TH to levels found in untreated controls, representing a $38 \%$ increase relative to animals that remained in their home cages without extinction training (Schmidt et al. 2001). A similar extinction-training regimen failed to alter TH levels in animals trained to self-administer sucrose pellets, despite the fact that responding extinguished to a similar extent under identical extinction training procedures. Thus, regulation of TH by extinction training does not reflect a generalized effect of the training procedure, or a neuroadaptive response to extinction learning, per se. Instead, this regulation represents a complex interaction between the neuroadaptive response to withdrawal from chronic cocaine self-administration and extinction experience itself. Moreover, an extinctioninduced normalization of $\mathrm{TH}$ levels could help to restore depleted dopamine stores, thereby reversing reward deficits associated with these early stages of cocaine withdrawal (Markou and Koob 1991; Koob and Le Moal 1997). In humans, cocaine withdrawal is described as a "crash" associated with dysphoria and depression often accompanied by anhedonia, and these effects gradually recover over several days (Lago and Kosten 1994; American Psychiatric Association 2000). Although there is little evidence that negative affect and dysphoria associated with withdrawal from cocaine or other drugs directly triggers relapse to drug seeking in animal studies (Self and Nestler 1998; Stewart 2003), these mood disturbances could augment the incentive value of drugs during withdrawal, possibly leading to persistent drug-seeking behavior (Hutcheson et al. 2001). Extinctioninduced normalization of $\mathrm{TH}$, with possible restoration of these affective disturbances, could dampen the ability of early withdrawal to facilitate the incentive value of cocaine upon relapse to drug use, and, thus, have potentially long-term benefits with further attempts to abstain.

In contrast to the NAc, TH levels in VTA dopamine neurons were not altered after $1 \mathrm{wk}$ of withdrawal from chronic cocaine self-administration (Schmidt et al. 2001). However, extinction training during the 1-wk withdrawal period increased $\mathrm{TH}$ in the VTA by about $45 \%$ of control levels. Thus, in both VTA and NAc, extinction-induced regulation represents an increase in TH relative to animals that remained in their home cages without extinction training, normalizing TH deficits in the NAc and increasing TH from baseline values in the VTA. These results suggest that normalization of TH deficits in the NAc could result from an increased TH synthesis in the VTA leading to greater transport to dopamine terminals in the NAc. Alternatively, extinction training could stabilize or impair degradation of TH in dopaminergic terminals of the NAc shell. In contrast to our results, another group found that cocaine self-administration alone increases $\mathrm{TH}$ levels in the VTA after $1 \mathrm{~d}$ but not 1 mo of withdrawal, and does not alter TH levels in NAc samples containing both core and shell tissue after any withdrawal period (Grimm et al. 2002; Lu et al. 2003). These discrepancies could result from differences in cumulative cocaine dose, rat strain, cocaine self-administration in home cages versus environmentally distinct test chambers, anterior-posterior planes of dissection (our tissue samples include more anterior regions of both VTA and NAc), or possible dilution of shell effects by inclusion of core tissue in NAc samples.

\section{Extinction-Induced Neuroplasticity in AMPA and NMDA Glutamate Receptors in the NAc Shell}

In addition to dopamine, the medium spiny neurons of the NAc also receive dense glutamatergic innervation from several cortical and subcortical regions. We previously reported that extinction training increases the amount of GluR1 and GluR2/3 subunits of AMPA glutamate receptors in the NAc shell subregion (Sutton et al. 2003). Figure 2 shows GluR1 data from this study along with new data on the NR1 subunit of NMDA receptors measured in the same NAc tissue samples and analyzed according to similar methods (see Materials and Methods). 
A NAc Shell

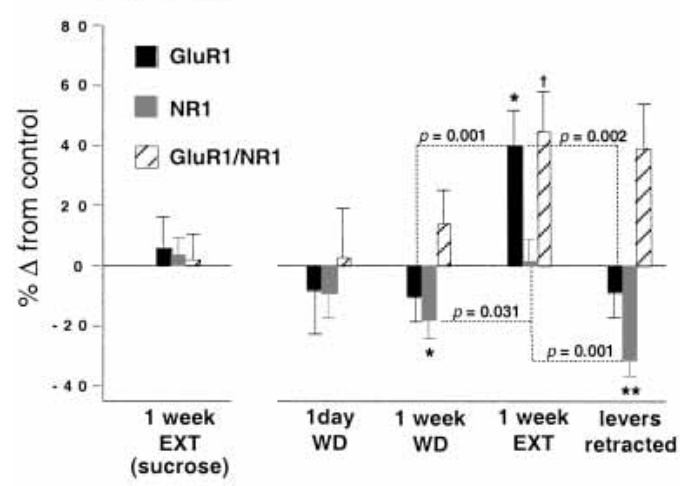

B NAc Core

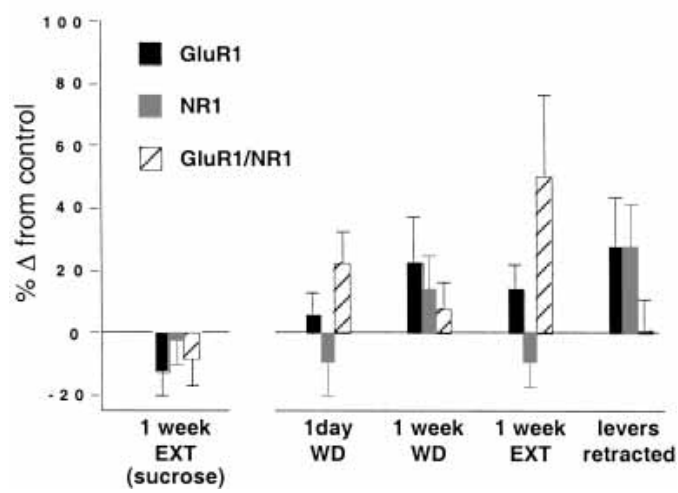

Figure 2 (A) Extinction training (EXT) for $4 \mathrm{~h} / \mathrm{d}$ during withdrawal (WD) from chronic cocaine self-administration increases immunoreactivity for GluR1 $\left(F_{(4,56)}=4.382, P=0.004\right)$, and reverses withdrawalinduced deficits in NR1 $\left(F_{(4,56)}=4.114, P=0.005\right)$ in homogenates of NAc shell tissue. Both effects require access to the response levers allowing extinction of cocaine-seeking responses at the drug-paired lever. Extinction training also increases the GluR1/NR1 ratio in cocaine-trained animals compared to similar extinction training procedures in animals trained to self-administer sucrose. (B) In contrast, there was no significant regulation of GluR1 and NR1 in the NAc core. Data are expressed as the mean \pm S.E.M. of percent change from age- and group-matched untreated control tissue. ${ }^{*} P<0.05 ;{ }^{*} P<0.01$ in cocaine-trained animals compared to NAc tissue from sucrose-trained animals subjected to identical extinction training procedures by Fisher's post-hoc tests $(\dagger P<0.05$ by Student's $t$-test corrected for multiple comparisons). Sample sizes (shell, core) are 1-wk EXT sucrose $(9,10) ; 1$-d WD $(9,8) ; 1$-wk WD (13, $11) ; 1$-wk EXT $(19,18)$; levers retracted $(11,10)$. GluR1 data are from Sutton et al. 2003 (with permission).

Extinction training increased GluR1 by 39\% (Fig. 2A), and GluR $2 / 3$ by $31 \%$ (data not shown), whereas levels of these subunits were not changed in animals left in their home cages for the same 1-wk withdrawal period. Similar to TH, extinctioninduced increases in GluR1 and GluR2/3 were not attributable to extinction-related learning or other procedural influences, as the levels failed to increase in animals extinguishing from sucrose self-administration under identical extinction training procedures. The GluR1 subunit also failed to increase in cocainetrained animals that were prevented from responding (levers retracted), but that experienced similar daily excursions to the selfadministration test chambers (Fig. 2A), indicating that increases in GluR1 require extinction of cocaine-seeking instrumental responses. In addition, the amount of GluR1 was associated positively with the degree of extinction achieved during training (Sutton et al. 2003). This positive association suggests that ex- tinction-induced increases in GluR1 could act reciprocally to facilitate extinction of cocaine-seeking behavior. In contrast, GluR2/3 AMPA receptor subunits increased even without access to the levers, indicating that repeated exposure to the selfadministration test chambers, and possibly extinction of Pavlovian rather than instrumental conditioning, was sufficient to increase GluR2/3.

In contrast to GluR1 and GluR2/3, the NR1 subunit of NMDA receptors decreased by $18 \%$ in the NAc shell after $1 \mathrm{wk}$ of withdrawal from chronic cocaine self-administration (Fig. 2A). However, extinction training prevented deficits in NR1, representing a $24 \%$ increase relative to animals remaining in their home cages for the same 1-wk withdrawal period. This effect also required access to the response levers, and hence, extinction of cocaine-seeking instrumental responses. NR1 levels also did not change in animals extinguishing from sucrose pellet selfadministration (Fig. 2A), again indicating that extinctioninduced regulation of NR1 (and AMPA receptor subunits) represents a specific interaction between extinction experience and the neurobiological effects of cocaine withdrawal. There was no significant regulation of NR1 in the NAc core subregion during cocaine withdrawal with or without extinction training, although GluR1 levels marginally (nonsignificantly) increased regardless of extinction training experience (Fig. 2B), and consistent with minor GluR1 up-regulation in a recent study examining combined core and shell subregions (Lu et al. 2003). Moreover, levels of GluR2/3 and NR1 were not significantly altered in the NAc core in any experimental group in our study (GluR2/3 levels ranged from $96 \% \pm 3 \%$ to $119 \% \pm 14 \%$ ), consistent with a lack of regulation in combined NAc core and shell tissue in withdrawal from chronic binge cocaine self-administration (Tang et al. 2004). In contrast, Lu et al. (2003) found substantial increases in both GluR2 and NR1 in combined core and shell NAc punches following chronic cocaine self-administration. Studies using forced cocaine administration by repeated bolus injection have also found increases (Churchill et al. 1999; Loftis and Janowsky 2000), decreases (Lu and Wolf 1999), and no effect (Fitzgerald et al. 1996) on AMPA and NMDA receptor subunit regulation in the NAc. Similar to cocaine-induced regulation of $\mathrm{TH}$, these discrepancies could result from differences in cocaine exposure, rat strain, housing conditions, planes of dissection, or marked sensitivity in GluR2 and NR1 regulation to other procedural differences in the NAc core.

Extinction-induced increases in AMPA and NMDA subunits (relative to withdrawal alone) in the NAc shell resemble similar activity-dependent regulation of ionotropic glutamate receptor subunits in sensory pathways following repeated sensory stimulation (Quinlan et al. 1999), or following high-frequency stimulation of excitatory synaptic inputs in hippocampal neurons in vivo (Heynen et al. 2000). In these studies, synaptic upregulation of GluR1 and GluR2 protein is associated with prolonged increases in synaptic excitability or long-term potentiation (LTP), indicating increased insertion of AMPA glutamate receptors in synaptic membranes. Indeed, a single high-frequency stimulus train sufficient to induce LTP also increases GluR1 and GluR2 (but not NR1) protein levels. Given that a majority of NAc neurons are highly activated during extinction from cocaine selfadministration (Fabbricatore et al. 1998), and neuronal activity is maintained even as cocaine-seeking responses extinguish, it is possible that similar activity-dependent synaptic regulation contributes to up-regulation in GluR1 and GluR2/3 protein levels in homogenates of NAc shell tissue. It should be noted, however, that LTP-related regulation is found only in synaptoneurosomal preparations, and not in homogenates of tissue surrounding the recording and stimulating electrodes (Heynen et al. 2000). It is possible that repeated high-frequency stimulation over several 
days, akin to repeated extinction training sessions, or longer time intervals between LTP induction and tissue harvesting, could lead to more global GluR1 and GluR2 up-regulation in tissue homogenates. In our study, synaptic, rather than gene, regulation is supported by the finding that extinction-induced increases in both GluR1 and GluR2/3 were not accompanied by increases in mRNAs for these subunits; instead, these mRNAs actually decreased (Sutton et al. 2003). Extinction-related activation of NAc neurons also could facilitate activity-dependent membrane insertion of AMPA receptors containing the GluR1 subunit (Shi et al. 2001; Takahashi et al. 2003), thereby strengthening excitatory input to the NAc similar to LTP.

In contrast to LTP, long-term depression (LTD) evoked by low-frequency stimulation is associated with decreases in synaptic levels of GluR1, GluR2, and NR1 protein, and reduced AMPAmediated excitatory input in hippocampal synapses (Heynen et al. 2000; Malinow and Malenka 2002). A similar LTD-like effect is produced by withdrawal from repeated cocaine treatment in cortico-accumbal synapses (Thomas et al. 2001). Interestingly, withdrawal-induced LTD is found specifically in the NAc shell, and not core, similar to down-regulation of NR1 in our study. Depressed synapses are highly susceptible to neuroplasticity caused by neuronal activation (Carroll et al. 2001), possibly explaining the regional selective effects of extinction training on both GluR1 and NR1 in the NAc shell. Moreover, down-regulation of NR1 in the NAc shell is consistent with LTD-induced downregulation of synaptic NR1 levels in the hippocampus in vivo (Heynen et al. 2000). However, in contrast to LTD in hippocampal synapses, levels of GluR1 and GluR2/3 were not significantly decreased by cocaine withdrawal, although extinction-induced "normalization" of NR1 in our study is consistent with normalization of NR1 (and LTD) by high-frequency stimulation (Heynen et al. 2000). Thus, whereas extinction-induced increases in GluR1 and GluR2/3 in the NAc resemble a state of LTP in potentiated hippocampal synapses, extinction-induced normalization of NR1 deficits resembles the effect of either reversing LTD or inducing LTP in hippocampal synapses.

Another important aspect of synaptic plasticity is the ratio of AMPA- to NMDA-mediated excitatory input. This ratio increases following LTP induction as more AMPA receptors are inserted in the synaptic membrane (Malinow and Malenka 2002). Similarly, the ratio of synaptic GluR1 to NR1 protein levels also increases following LTP in the hippocampus (Heynen et al. 2000). Therefore, we compared individual GluR1/NR1 ratios in the NAc to determine whether the ratio of these subunits changes as a consequence of cocaine withdrawal or extinction training. Figure 2A shows that extinction training during cocaine withdrawal increased the ratio of GluR1 to NR1 protein compared to animals extinguishing from sucrose self-administration, whereas this ratio failed to increase in cocaine withdrawal without extinction. These results are consistent with a state of LTP at excitatory synapses in the NAc shell following extinction training. Marginal (nonsignificant) increases in the GluR1/NR1 ratio were found when access to the response levers was denied during exposure to the self-administration test chambers, but primarily due to deepening withdrawal-induced NR1 deficits rather than GluR1 up-regulation.

Recent evidence suggests that AMPA and NMDA currents are tightly coregulated such that increases in AMPA currents following LTP induction are eventually accompanied by slowerforming increases in NMDA currents (Watt et al. 2004). Similar coregulation could explain the increased NR1 levels (relative to withdrawal) that accompanied increased AMPA subunits in extinction-trained animals. However, although extinction training increased both GluR1 and NR1 relative to cocaine withdrawal alone, the ratio remained biased towards GluR1 following extinction training, possibly reflecting dysfunctional coregulation of AMPA and NMDA receptor-mediated excitatory input. It also is likely that GluR and NR subunit protein levels do not accurately reflect changes in synaptic strength, although other studies have found that overexpression of GluR1 and GluR2 protein increases membrane expression and AMPA-mediated responses both in vitro and in vivo (Passafaro et al. 2001; Takahashi et al. 2003). Clearly, future studies are needed to determine whether extinction training induces LTP (or reverses LTD) in cortico-accumbal synapses, and whether alterations in GluR1/NR1 protein ratios are reflected by similar alterations in AMPA and NMDA receptormediated currents.

\section{Extinction-Induced Regulation of Gene Expression in Cocaine Withdrawal}

Microarray profiling is a powerful tool for identifying novel changes in gene expression associated with drug addiction. We have used oligonucleotide microarrays to identify several novel changes in gene expression in the NAc core and shell in cocaine withdrawal, and their regulation by extinction training (Simmons et al. 2002). Table 1 summarizes some of the changes in gene expression that have been confirmed at the protein level by Western blot analysis. In some cases, extinction training reversed or normalized changes in gene expression during withdrawal from chronic cocaine self-administration, whereas in other cases, extinction training increased gene expression from baseline control levels.

One change in particular may have important implications for extinction-induced regulation of AMPA receptors discussed above. Figure $3 \mathrm{~A}$ shows that extinction training induced a 2.4fold $(140 \%)$ increase in the expression of a novel integral membrane receptor that interacts with neuronal pentraxins 1 and 2 (Dodds et al. 1997). Neuronal pentraxin 2, otherwise known as Narp (neuronal activity-regulated pentraxin), is an immediate early gene induced by synaptic activity. The Narp protein is en-

Table 1. Modulation of Gene and Protein Expression by Extinction Training in Cocaine Withdrawal.

\begin{tabular}{|c|c|c|c|c|}
\hline \multirow[b]{2}{*}{ Regulated genes } & \multicolumn{2}{|c|}{ Cocaine withdrawal } & \multicolumn{2}{|c|}{ Extinction training } \\
\hline & mRNA & Protein & mRNA & Protein \\
\hline CB1 cannabinoid receptor & $\uparrow$ & $\downarrow$ & normalized & normalized \\
\hline Mu1 opioid receptor & $\uparrow$ & $\uparrow$ & normalized & normalized \\
\hline GABAB2 receptor & normal & normal & $\uparrow$ & $\uparrow$ \\
\hline Neuronal pentraxin (Narp) receptor & normal & $\downarrow$ (Narp) & $\uparrow$ & normalized (Narp) \\
\hline A-kinase anchor protein 84 & $\downarrow$ & $\uparrow$ & normalized & normalized \\
\hline $\mathrm{Kv} 4.3 \mathrm{~K}^{+}$channel & $\uparrow$ & $\downarrow$ & normalized & normalized \\
\hline Zif 268 & $\downarrow$ & $\uparrow$ & normalized & normalized \\
\hline Microtubule-associated protein 2 & $\downarrow$ & $\downarrow$ & $\uparrow$ & $\uparrow$ \\
\hline
\end{tabular}




\section{A NPR mRNA}

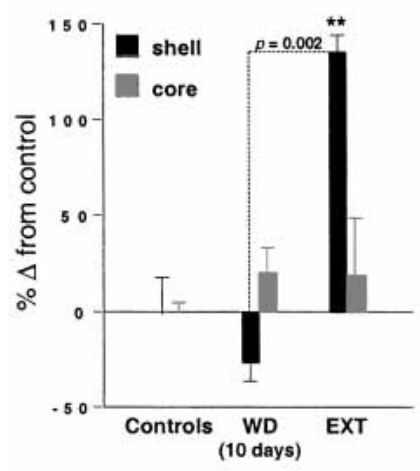

\section{B Narp protein}

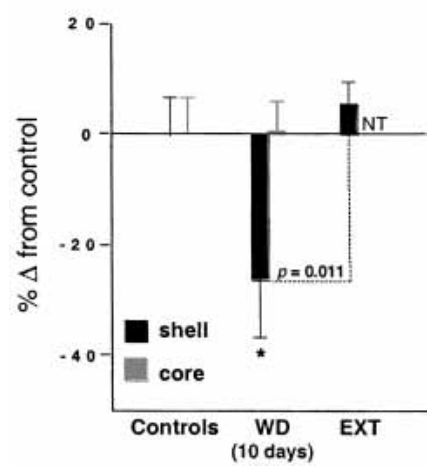

Figure 3 Extinction training (EXT) during withdrawal (WD) from chronic cocaine self-administration increases expression of a novel neuronal pentraxin receptor (NPR) in the NAc shell and Narp (neuronal activity-regulated pentraxin) protein that interacts with NPR. (A) Extinction training induces expression of NPR mRNA $\left(F_{(2,5)}=20.123, P=0.004\right)$. $(B)$ Extinction training reverses withdrawal-induced deficits in Narp protein $\left(F_{(2,32)}=4.465 P=0.019\right)$ in homogenates of NAc shell tissue. In contrast, there are no changes in NPR mRNA or Narp protein in adjacent punches of NAc core tissue. Changes in mRNA levels were identified by microarray profiling (Affymetrix rat chips) of mRNA from pooled NAc core and shell tissue samples $(n=5 /$ pool) in untreated control (four pools), WD and EXT groups (two pools each) in two independent comparisons (see Materials and Methods). ${ }^{*} P<0.05 ;{ }^{* *} P<0.01$ compared to untreated age- and batch-matched control tissue by Fisher's post-hoc tests. Sample sizes for Western blot analysis of Narp (shell, core) are 10-d WD $(10,8)$, EXT $(9$, shell only), and pooled untreated controls $(16,7)$. NT, not tested.

riched in excitatory synapses, where it plays an important role in aggregating large clusters of surface AMPA receptors at the synapse (O'Brien et al. 1999). Narp is induced by LTP, and Narp overexpression increases the number of excitatory synapses in cultured neurons. We found that levels of Narp protein are reduced by $27 \%$ after 10 -d withdrawal from chronic cocaine selfadministration in the NAc shell (Fig. 3B). In contrast, extinction training normalized these deficits in Narp, reflecting a $43 \%$ increase from cocaine withdrawal without extinction training.

Extinction-induced increases in the neuronal pentraxin receptor could influence Narp levels by sequestering Narp in synaptic membranes, thereby reversing Narp deficits in cocaine withdrawal. Furthermore, extinction-induced up-regulation of both neuronal pentraxin receptor and Narp were found only in the NAc shell, and not core, similar to the extinction-induced regulation of AMPA receptor subunits. Therefore, extinctioninduced increases in Narp protein (relative to withdrawal) could increase the formation of large aggregates of surface AMPA re-

ceptors, thereby contributing to parallel increases in GluR1 and GluR2/3 levels. Conversely, decreases in Narp protein during cocaine withdrawal could contribute to a loss of surface AMPA receptors associated with LTD in the NAc shell.

Another change in gene expression specifically related to extinction training is increased expression of the GABA B2 receptor (mRNA and protein) in the NAc shell (Table 1), which could represent a compensatory up-regulation in inhibitory input that parallels increases in AMPA receptor subunits. Extinction training also reversed withdrawal-induced deficits in the microtubule-associated protein MAP2 in the NAc, and instead caused an increase in both mRNA and protein levels relative to untreated controls. MAP2 is a marker for dendritic proliferation, and its down-regulation in cocaine withdrawal is consistent with down-regulation of other postsynaptic proteins such as PSD-95 in striatal tissue following repeated cocaine treatment (Yao et al. 2004). Apparently, down-regulation in these markers of dendritic and spine proliferation may occur despite increases in dendritic branching and spine formation in cocaine withdrawal (Robinson et al. 2001). In addition, extinction-induced increases in MAP2 could indicate that extinction training leads to substantial reorganization in dendritic morphology in the NAc shell.

Extinction training normalized many other changes in early (10-d) cocaine withdrawal, including opposite regulation of mRNA and protein levels for the CB1 cannabinoid receptor and the immediate early gene Zif 268 (Table 1). Such opposing regulation could reflect compensatory adaptations in gene expression to changes in protein levels, or regulation of protein levels primarily through degradation rather than synthetic pathways. Following long-term cocaine withdrawal (6 wks), extinction training (during the final week) also normalized bidirectional regulation of mRNA and protein for the Kv 4.3 potassium channel, and the A-kinase anchoring protein AKAP 84. Given that chronic exposure to cocaine (and other drugs) is known to up-regulate protein kinase A in the NAc (Self and Nestler 1995, 1998), increases in AKAP 84 could target this up-regulation to specific cellular or synaptic compartments. In addition, a late-forming up-regulation in the $\mu$ opioid receptor MOR1 (mRNA and protein) that arises after 3-6 wks of cocaine withdrawal is completely normalized by extinction training during the sixth week of withdrawal. These latter findings suggest that extinction training can normalize persistent neuroadaptations even after prolonged abstinence that otherwise may contribute to the propensity for relapse.

\section{GluR1 and GluR2 in NAc Shell Neurons Facilitate Extinction and Attenuate Reinstatement}

As discussed earlier, we found a positive association between extinction-induced increases in GluR1 and the level of extinction achieved during training, suggesting that GluR1 up-regulation could act reciprocally to facilitate extinction of cocaine-seeking behavior. We tested this hypothesis using viral-mediated gene transfer in vivo to overexpress GluR1 and GluR2 subunits in NAc shell neurons prior to extinction testing. Intra-NAc infusions of HSV (Herpes Simplex Virus)-GluR1 or HSV-GluR2 produced transient ( 4-5-d) GluR overexpression confined to the medial NAc shell region (Sutton et al. 2003). Both GluR1 and GluR2 overexpression reduced cocaine-seeking responses at the drug-paired lever during initial extinction tests, and shortened the latency to achieve extinction criterion by 1.5-2 training sessions compared to controls. In contrast, neither GluR1 nor GluR2 overexpression altered extinction from sucrose self-administration, thereby eliminating the possibility of generalized performance effects on lever-press behavior. These results suggest that up-regulation in GluR1 and GluR2/3, as a consequence of repeated extinction 
training, could act to facilitate the extinction of cocaine-seeking behavior. This effect could involve a direct reduction in the motivation for cocaine, or an indirect facilitation of "cocainespecific" extinction learning, by increasing excitatory input to NAc shell neurons.

If GluR1 and GluR2 facilitate extinction learning, then animals should exhibit greater recall of extinction memory when tested after GluR1 and GluR2 overexpression declined. However, in animals that experienced a single 4-h extinction training session during GluR1 or GluR2 overexpression, the remainder of cocaine-seeking behavior extinguished at normal rates when tested after GluR1 and GluR2 overexpression declined (Sutton et al. 2003). This finding could suggest that extinction-induced upregulation in GluR1 and GluR2/3 does not facilitate extinction learning, but, rather, that AMPA receptor-mediated excitatory input to the NAc shell directly mediates inhibitory control over the motivation for cocaine. The latter conclusion would seem contrary to other findings showing that direct activation of NAc neurons via intra-NAc AMPA infusions reinstates cocaine-seeking behavior (Cornish et al. 1999; Cornish and Kalivas 2000), and that AMPA receptor-mediated neurotransmission in the core, but not shell, is necessary to maintain cocaine seeking (Di Ciano and Everitt 2001; Ito et al. 2004). One possibility is that generalized activation or inactivation of AMPA receptors disrupts inhibitory control over motivated behavior emanating from cortical or other glutamatergic input to the NAc shell, and that preserving temporal/spatial integration of endogenous synaptic activity, and the information carried by this activity, is important for the inhibitory effects of GluR1 and GluR2 on cocaine seeking. Alternatively, glutamatergic inputs may differentially carry information relating to both incentive motivational and behavioral inhibition. In this case, phasic activation of glutamatergic inputs (as produced by agonist infusions) may be more related to transient activation by motivationally salient stimuli, whereas tonic up-regulation (as with GluR1 and GluR2 overexpression) may alter background in excitatory responses and reduce the signalto-noise ratio with phasic activation, hence, reducing the motivational response. Regarding the latter possibility, tonic elevations in extracellular glutamate levels also reduce reinstatement of cocaine-seeking behavior (Baker et al. 2003).

In addition to direct inhibitory effects on cocaine-seeking behavior, transient GluR1 and GluR2 overexpression in NAc shell neurons during a single extinction training session produced a long-term attenuation of stress-induced reinstatement of cocaine seeking (Sutton et al. 2003). Thus, a brief (30-min) exposure to mild intermittent footshock stress failed to reinstate cocaineseeking behavior in animals overexpressing GluR1 and GluR2 during prior extinction training, despite having no effect on reinstatement induced by exposure to cocaine-conditioned cues or priming injections of cocaine. The reinstatement paradigm is thought to model cocaine craving, and has some face validity because similar conditioned, stress-related, and drug stimuli trigger cocaine craving in humans (Jaffe et al. 1989; Robbins et al. 1997; Sinha et al. 1999).

Increased levels of GluR1 and GluR2, and presumably increased excitatory input to NAc shell neurons, may directly reduce the motivation for cocaine, but our results suggest that they do not generally facilitate extinction learning with other appetitive rewards, and do not lead to greater recall of extinction memory when tested after overexpression declined. However, a learning-specific interaction is indicated by our results, because temporally dissociating GluR1 overexpression from extinction training experience prevented the subsequent inhibition of stress-induced reinstatement (Sutton et al. 2003). Thus, when initial extinction training sessions were delayed until after GluR1 overexpression declined to normal levels, the ability of footshock stress to reinstate cocaine seeking was completely restored. One possibility is that frustrative stress associated with initial exposure to extinction conditions imposes state-dependent effects on extinction learning, and that recall of extinction memory is enabled by re-exposure to similar stressful situations during stressinduced reinstatement (D. Self and K.-H. Choi, in prep.). Initial exposure to extinction conditions is associated with multiple stress-related neurochemical responses, including release of the endogenous opiate $\beta$-endorphin in the NAc, as discussed earlier (Roth-Deri et al. 2003; Zangen and Shalev 2003). $\beta$-endorphin and other opiates have been shown to impart state-dependent learning effects in other aversive training procedures (Izquierdo et al. 1980; de Almeida and Izquierdo 1984). Thus, it is possible that GluR1 and GluR2 overexpression in the NAc shell facilitated extinction learning during the initial session when frustrative stress is high, but recall was masked until animals were exposed to similar stressful situations. In any event, these results suggest that extinction-induced increases in GluR1 and GluR2 in the NAc shell act reciprocally with extinction experience itself to ultimately weaken the neural substrates of stress-induced relapse.

\section{Other Possible Benefits of Extinction Training on Addictive Behavior}

Extinction training procedures have been used to attenuate conditioned responses to cocaine-related stimuli in humans, including objective measurements of accelerated heart rate and galvanic skin responses, and subjective measurements of anxiety and craving (O'Brien et al. 1990; Foltin and Haney 2000), although their effectiveness in preventing future relapse has not been established. Our studies suggest that extinction-induced regulation of glutamate receptors could restore deficits in excitatory input to the NAc that contribute to relapse. For example, chronic cocaine use produces multiple deficits in glutamatergic neurotransmission in the NAc, including sustained hypoactivity and decreased gray matter in frontal cortical regions that project to the NAc (Volkow et al. 1992; London et al. 1999; Volkow and Fowler 2000; Franklin et al. 2002), reduced presynaptic and extracellular levels of glutamate in the NAc (Keys et al. 1998; Bell et al. 2000; Baker et al. 2003), and postsynaptic subsensitivity in NAc neurons to glutamate and AMPA (White et al. 1995; Thomas et al. 2001). Given the similarities between extinction-induced up-regulation in AMPA and NMDA receptor subunits and induction of LTP (or reversal of LTD), extinction training could revert synaptic depression to potentiation and restore excitatory input to NAc shell neurons in cocaine withdrawal (Fig. 4). As both LTD and extinction-induced regulation of AMPA and NMDA subunits are found only in the NAc shell, and extinction training fails to regulate AMPA subunits in cocaine-naive rats, it is possible that LTD enables extinction-induced neuroplasticity in cortico-NAc shell synapses in cocaine withdrawal. In this regard, the NAc of addicted people may be particularly sensitive to a variety of learning- and activity-related influences while in this vulnerable state.

Excitatory glutamatergic afferents to the NAc emanating from medial prefrontal cortex are thought to regulate behavioral inhibition and exert control over impulsive responding (Weissenborn et al. 1997; Jentsch and Taylor 1999; Christakou et al. 2004). Most of these studies have focused primarily on prelimbic cortical regions that innervate the NAc core, although many prelimbic cortical neurons also innervate the NAc shell (Brog et al. 1993; Berendse et al. 1992; Wright and Groenewegen 1995). In contrast, infralimbic cortical neurons are thought to innervate only the NAc shell (Ongur and Price 2000), but also have been implicated in the inhibition of impulsive responding (Chudasama and Robbins 2003). Lesions of the NAc core produce 

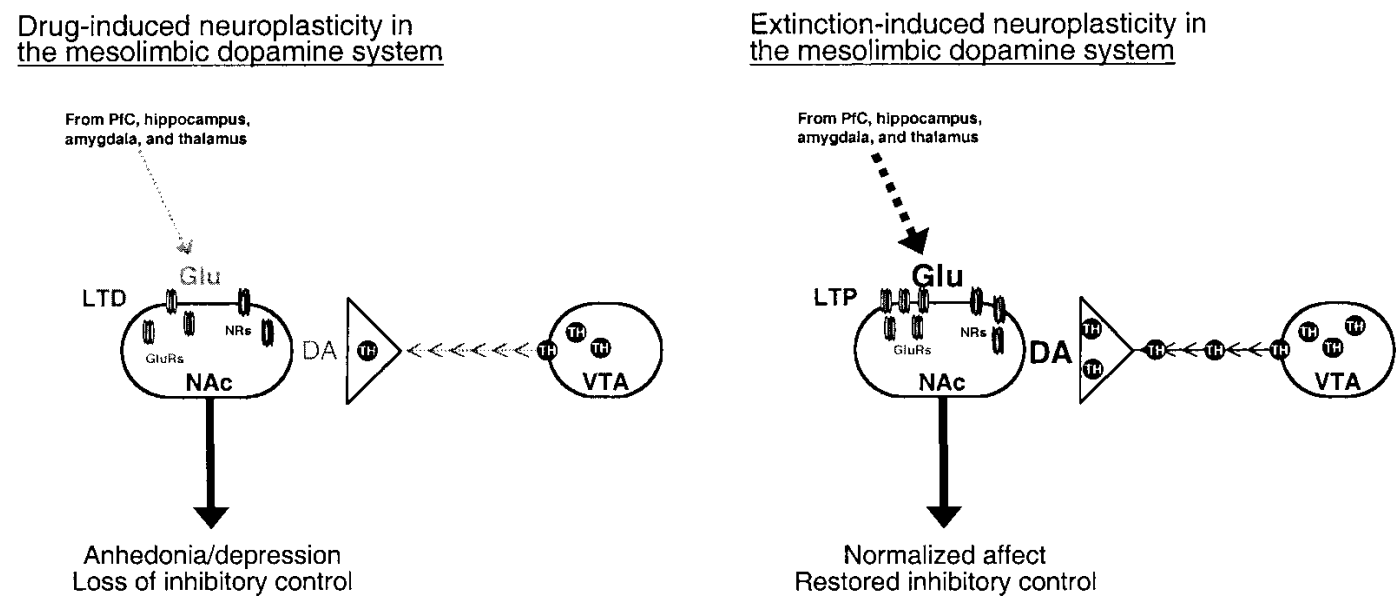

Figure 4 Hypothetical behavioral consequences of drug- and extinction-induced neuroplasticity in the ventral tegmental area (VTA) and nucleus accumbens (NAc). Drug-induced changes include a deficit in the rate-limiting enzyme for dopamine (DA) synthesis, tyrosine hydroxylase (TH), in dopaminergic terminals of the NAc shell that could contribute to negative mood disturbances including dysphoria, anhedonia, and depression in early stages of cocaine withdrawal. Extinction-induced normalization of TH levels in the NAc shell, possibly the result of increased TH synthesis and transport from the VTA, would help to normalize affective disturbances by restoring extracellular dopamine levels. In addition, extinction-induced up-regulation in AMPA and NMDA glutamate (Glu) receptor subunits in the NAc shell resemble changes found in potentiated synapses. Extinction-induced increases in GluR1, and normalization of NR1, could revert LTD to LTP in excitatory synapses emanating from cortical and thalamic regions during drug withdrawal. Restoration of excitatory synaptic input to NAc shell neurons is hypothesized to restore inhibitory control over drug-seeking behavior.

impulsive responding in operant procedures (Johansson and Hansen 2000; Cardinal et al. 2001; Christakou et al. 2004), although the effects of shell lesions were not compared in these studies. Together these studies suggest that prefrontal cortical innervation of the NAc core and possibly shell mediates inhibitory control over goal-directed behavior.

In contrast to their role in response inhibition, medial prefrontal cortical regions also are activated during cocaine craving in humans (e.g., Grant et al. 1996; Childress et al. 1999), and animal studies suggest that cortical regions projecting to the NAc core, but not shell, mediate cue- and stress-induced reinstatement of cocaine seeking (Cornish et al. 1999; Cornish and Kalivas 2000; Di Ciano and Everitt 2001; Capriles et al. 2003; McFarland et al. 2003; McLaughlin and See 2003; Ito et al. 2004). Another study suggests that AMPA and NMDA receptors in the NAc core exert opposite effects on cocaine-seeking behavior, with an inhibitory role for NMDA receptors (Park et al. 2002). These differences highlight the role of prefrontal cortical projections in multiple aspects of cocaine seeking, including evaluation of emotional valence, choice, and both the execution and inhibition of goal-directed behavior.

Given the general role for excitatory neurotransmission in information processing, it is not surprising that excitatory inputs to NAc neurons could carry information relating to both facilitation and inhibition of cocaine-seeking behavior. Moreover, the role of ionotropic glutamate receptors in directly transmitting, rather than modulating, neural information that requires complex temporal and spatial integration for cognitive processing may render itself somewhat inaccessible to clear-cut analysis by traditional neuropharmacological and anatomical approaches. Our studies utilize molecular approaches that increase AMPA receptor-mediated responses while preserving endogenous synaptic activity, and these studies support an inhibitory role for this activity on cocaine-seeking behavior in the NAc shell (Fig. 4). These effects, along with regulation of $\mathrm{TH}$ described earlier, suggest that extinction-induced changes in the mesolimbic dopamine system could produce beneficial behavioral effects in addicted people. Possible direct benefits include enhanced inhibitory control over the urge for cocaine and normalization of mood disturbances, whereas indirect benefits may include attenuation of stress-induced cravings in prolonged abstinence.

It is widely believed that neuroadaptations to addictive drugs result primarily from their unconditioned pharmacological effects. However, our studies underscore the important contribution of experiential factors in ultimately determining brain responses to chronic drug self-administration. These initial studies suggest that extinction training can profoundly reverse or ameliorate the harmful neurobiological consequences of chronic drug use, and in some instances their contribution to addictive behavior, but further studies are needed in order to understand the cellular mechanisms underlying this regulation. Our studies also suggest that even short-term extinction-based treatment strategies could produce substantial long-term benefits. Clearly, treatment strategies that incorporate extinction training offer a nonpharmacological, behavior-based approach that often is overlooked by pharmaceutical-driven therapeutics.

\section{MATERIALS AND METHODS}

\section{Behavioral Procedures}

NR1 data are from the same tissue samples used for analysis of GluR1 and GluR2/3 in Sutton et al. (2003). Briefly, male SpragueDawley rats (300-350 g) were housed individually in accordance with NIH (National Institutes of Health, USA) standards, and received lever-press training for sucrose pellets $(45 \mathrm{mg})$ in twolever Med Associates operant test chambers to facilitate acquisition of cocaine self-administration. Following criteria for leverpress training (100 sucrose pellets for 3 consecutive d), animals were fed ad libitum prior to intravenous catheterization as described (Schmidt et al. 2001). Age- and group-matched biochemical controls also received lever-press training, but remained in their home cages until tissue collection. At least $4 \mathrm{~d}$ following catheterization, animals were allowed to acquire cocaine selfadministration during their dark cycle by pressing the active lever (fixed ratio 1:time-out 15 -sec schedule) in daily 4 -h test sessions $6 \mathrm{~d} /$ wk for $12 \mathrm{~d}$. A compound stimulus (cue light/pump noise/house lights off) accompanied each cocaine injection (1.0 $\mathrm{mg} / \mathrm{kg}$ ) delivered in $0.1 \mathrm{~mL}$ sterile saline over $10 \mathrm{sec}$ during the 15 -sec time-out period. Average cocaine intake over the last $5 \mathrm{~d}$ of 
self-administration ranged between $38.6-43.6 \mathrm{mg} / \mathrm{kg} / \mathrm{d}$ across study groups. Sucrose-trained animals were maintained at $85 \%$ initial body weight and self-administered sucrose pellets (fixed ratio 1) for $4 \mathrm{~h} / \mathrm{d}$ or until a maximum of 100 pellets were earned.

Extinction training was conducted in six daily 4-h sessions in the absence of cocaine/cue reinforcement. Both sucrose- (fed ad lib) and cocaine-trained animals extinguished to a mean $7.5 \pm 3.0$ responses $/ h$ and $7.0 \pm 1.4$ responses $/ h$, respectively, prior to tissue collection. Brain tissue was collected $12-16 \mathrm{~h}$ after the last extinction training session after $1 \mathrm{wk}$ of withdrawal from cocaine self-administration.

Microarray and subsequent Western blot analyses were conducted in brain tissue from animals that acquired cocaine selfadministration under similar conditions but without prior lever press training. These animals self-administered cocaine during their dark cycle $5 \mathrm{~d} /$ wk over 3 wks (week 1:10 h/d; weeks 2-3: 6 $\mathrm{h} / \mathrm{d}$ ), and extinction training was conducted for $6 \mathrm{~h} / \mathrm{d}$ for five consecutive days during early (days 3-7) or late (days 38-42) phases of cocaine withdrawal. Brain tissue was collected $3 \mathrm{~d}$ after the last extinction training session after 10-d (early) or 45-d (late) withdrawal from cocaine self-administration. In all experiments, study groups were composed of animals received and tested on at least three separate occasions to control for possible batch or other procedural influences.

\section{Immunoblot Procedures}

Rats were removed from their home cages and immediately decapitated in a separate room; the brains were rapidly dissected and chilled in ice-cold phosphate-buffered saline ( $\mathrm{pH}$ 7.4). NAc core samples were obtained with a 14-gauge punch from chilled coronal brain slices $(0.7-2.2 \mathrm{~mm}$ anterior to bregma), immediately frozen and stored at $-80^{\circ} \mathrm{C}$. Half moon-shaped NAc shell samples were obtained with a 12-gauge punch of the remaining ventral-medial shell tissue. Contralateral tissue punches (balanced for left and right side) were collected in two independent pools for analysis by microarray profiling.

Individual tissue samples for Western blot analysis of NR1 and Narp were homogenized by sonication in $350 \mu \mathrm{L}$ of a buffer consisting of $320 \mathrm{mM}$ sucrose, $5 \mathrm{nM}$ HEPES pH 7.4, $50 \mathrm{mM} \mathrm{NaF}$, $1 \%$ SDS, Phosphatase Inhibitor Cocktail I and II (Sigma), and Protease Inhibitor Cocktail (Sigma). Protein concentrations were determined by the Bio-Rad DC Protein Assay based on the method by Lowry et al. (1951), and $20 \mu \mathrm{g}$ protein/sample was subjected to SDS-polyacrylamide gel electrophoresis $(7.5 \%$ or $10 \%$ acrylamide), followed by electrophoretic transfer to ImmunBlot PVDF membrane (Bio-Rad). NR1 was immunolabeled with rabbit anti-NR1 (1:500; Upstate) and Narp with mouse antipentraxin (1:500, BD Biosciences) incubated overnight at $4^{\circ} \mathrm{C}$ in blocking buffer consisting of 5\% Blotting Grade Blocker (Bio-Rad) in TTBS (100 mM Tris-base pH 7.4, $150 \mathrm{mM} \mathrm{NaCl}, 1 \%$ Tween-20). Following incubation with the primary antibody, blots were washed three times with TTBS, and incubated for $1 \mathrm{~h}$ at room temperature with horseradish peroxidase-conjugated goat antirabbit $(1: 50,000)$ or goat anti-mouse $(1: 25,000)$ antibody (Chemicon) in TTBS. The blots were washed three times in TTBS, and immunoreactivity visualized using enhanced chemiluminescence for peroxidase labeling (SuperSignal Dura West, Pierce). Immunoreactivity was quantified by densitometric analysis using NIH Image 1.62 (National Institutes of Health). Immunoreactivity was determined to be linear over a fourfold range of tissue concentrations under these conditions. Data are expressed as a percentage of the mean of 7-10 controls alternating with experimental samples on each gel. Experimental groups were analyzed by one-way ANOVA followed by post-hoc comparisons with Fisher's tests (or Student's $t$-tests corrected for multiple comparisons).

\section{Microarray Profiling Procedures}

Total RNA was isolated from pooled NAc shell or core samples $(n=5 /$ pool) after 1 or 6 wks of withdrawal, with or without extinction training during the final week, and from their age-and group-matched controls, using Trizol reagent (Gibco BRL), and purified with RNeasy columns (QIAGEN). Replicates consisted of $50 \mathrm{ng}$ total RNA from two independent pools subjected to two rounds of cDNA synthesis and linear cRNA amplification to produce enough material for hybridization to Affymetrix Gene Chip Rat Genome RGU34A arrays (Scherer et al. 2003). Arrays were washed and stained with standard Affymetrix reagents. Arrays were scanned with an Affymetrix scanner (model GA 2500). Data were analyzed with MAS4 (Affymetrix) by global scaling to a target intensity of 200. Two different filters were used to find differentially expressed transcripts. The intersection of the filters was reported. In the first filter, intensity values from MAS4processed CEL files were forced to a minimum value of 20 , and t-tests were performed. Probe sets were retained only after they met the following criteria: (1) $P$-value less than 0.01 , (2) at least 1.5 -fold change between groups, and (3) maximum intensity value across the groups of at least 200 . The second filtering method used the coefficient of variation $(\mathrm{CV})$ between the replicates with intensity values forced to minimum of 200. Probe sets were retained only if they met the following criteria: (1) at least 1.5-fold change difference between groups, and (2) less than 0.25 for the CV between replicates of all groups in the comparison.

\section{ACKNOWLEDGMENTS}

This work was supported by USPHS grant DA 10460, DA 08227, DA 0013796, and by the Lydia Bryant Test Professorship.

\section{REFERENCES}

American Psychiatric Association. 2000. Diagnostic and statistical manual of mental disorders, 4th ed. Text revision. American Psychiatric Association, Washington, DC.

Baker, D.A., McFarland, K., Lake, R.W., Shen, H., Tang, X.C., Toda, S., and Kalivas, P.W. 2003. Neuroadaptations in cystine-glutamate exchange underlie cocaine relapse. Nat. Neurosci. 6: 743-749.

Beitner-Johnson, D. and Nestler, E.J. 1991. Morphine and cocaine exert common chronic actions on tyrosine hydroxylase in dopaminergic brain reward regions. J. Neurochem. 57: 344-347.

Bell, K., Duffy, P., and Kalivas, P.W. 2000. Context-specific enhancement of glutamate transmission by cocaine. Neuropsychopharmacology 23: 335-344.

Berendse, H., Galis-de Graaf, Y., and Groenewegen, H. 1992. Topographical organization and relationship with ventral striatal compartments of prefrontal corticostriatal projections in the rat. $J$. Comp. Neurol. 316: 314-347.

Bouton, M.E. 2002. Context, ambiguity, and unlearning: Sources of relapse after behavioral extinction. Biol. Psychiat. 52: 976-986.

Brock, J.W., Ng, J.P., and Justice Jr., J.B. 1990. Effect of chronic cocaine on dopamine synthesis in the nucleus accumbens as determined by microdialysis perfusion with NSD-1015. Neurosci. Lett. 117: 234-239.

Brog, J.S., Salyapongse, A., Deutch, A.Y., and Zahm, D.S. 1993. The patterns of afferent innervation of the core and shell in the "accumbens" part of the ventral striatum: Immunohistochemical detection of retrogradely transported fluoro-gold. J. Comp. Neurol. 338: $255-278$.

Cadoni, C., Solinas, M., and Di Chiara, G. 2000. Psychostimulant sensitization: Differential changes in accumbal shell and core dopamine. Eur. J. Pharmacol. 388: 69-76.

Capriles, N., Rodaros, D., Sorge, R.E., and Stewart, J. 2003. A role for the prefrontal cortex in stress- and cocaine-induced reinstatement of cocaine seeking in rats. Psychopharmacology 168: 66-74.

Cardinal, R.N., Pennicott, D.R., Sugathapala, C.L., Robbins, T.W., and Everitt, B.J. 2001. Impulsive choice induced in rats by lesions of the nucleus accumbens core. Science 292: 2499-2501.

Carlezon Jr., W.A., Devine, D.P., and Wise, R.A. 1995. Habit-forming actions of nomifensine in nucleus accumbens. Psychopharmacology 122: 194-197.

Carroll, R.C., Beattie, E.C., von Zastrow, M., and Malenka, R.C. 2001. Role of AMPA receptor endocytosis in synaptic plasticity. Nat. Rev. Neurosci. 2: 315-324.

Childress, A.R., Mozley, P.D., McElgin, W., Fitzgerald, J., Reivich, M., and O'Brien, C.P. 1999. Limbic activation during cue-induced cocaine craving. Am. J. Psychiat. 156: 11-18.

Christakou, A., Robbins, T.W., and Everitt, B.J. 2004. Prefrontal cortical-ventral striatal interactions involved in affective modulation of attentional performance: Implications for corticostriatal circuit function. J. Neurosci. 24: 773-780.

Chudasama, Y. and Robbins, T.W. 2003. Dissociable contributions of 
the orbitofrontal and infralimbic cortex to Pavlovian autoshaping and discrimination reversal learning: Further evidence for the functional heterogeneity of the rodent frontal cortex. J. Neurosci. 23: 8771-8780.

Churchill, L., Swanson, C.J., Urbina, M., and Kalivas, P.W. 1999. Repeated cocaine alters glutamate receptor subunit levels in the nucleus accumbens and ventral tegmental area of rats that develop behavioral sensitization. J. Neurochem. 72: 2397-2403.

Cornish, J. and Kalivas, P. 2000. Glutamate transmission in the nucleus accumbens mediates relapse in cocaine addiction. J. Neurosci. 20: RC89.

Cornish, J.L., Duffy, P., and Kalivas, P.W. 1999. A role for nucleus accumbens glutamate transmission in the relapse to cocaine-seeking behavior. Neuroscience 93: 1359-1367.

Davis, H., Memmott, J., Macfadden, L., and Levine, S. 1976. Pituitary-adrenal activity under different appetitive extinction procedures. Physiol. Behav. 17: 687-690.

de Almeida, M.A. and Izquierdo, I. 1984. Effect of the intraperitoneal and intracerebroventricular administration of ACTH, epinephrine, or $\beta$-endorphin on retrieval of an inhibitory avoidance task in rats. Behav. Neur. Biol. 40: 119-122.

Diana, M., Pistis, M., Carboni, S., Gessa, G., and Rossetti, Z.L. 1993. Profound decrement of mesolimbic dopaminergic neuronal activity during ethanol withdrawal syndrome in rats: Electrophysiological and biochemical evidence. Proc. Natl. Acad. Sci. 90: 7966-7969.

Di Ciano, P. and Everitt, B.J. 2001. Dissociable effects of antagonism of NMDA and AMPA/KA receptors in the nucleus accumbens core and shell on cocaine-seeking behavior. Neuropsychopharmacology 25: $341-360$

Dodds, D.C., Omeis, I.A., Cushman, S.J., Helms, J.A., and Perin, M.S. 1997. Neuronal pentraxin receptor, a novel putative integral membrane pentraxin that interacts with neuronal pentraxin 1 and 2 and taipoxin-associated calcium-binding protein 49. J. Biol. Chem. 272: 21488-21494.

Dworkin, S.I., Co, C., and Smith, J.E. 1995. Rat brain neurotransmitter turnover rates altered during withdrawal from chronic cocaine administration. Brain Res. 682: 116-126.

Fabbricatore, A., Uzwiak, A., West, M., and Peoples, L. 1998. Comparisons of firing rates of rat nucleus accumbens neurons during cocaine self-administration and extinction. Soc. Neurosci. Abstr. 24: 1736.

Fitzgerald, L.W., Ortiz, J., Hamedani, A.G., and Nestler, E.J. 1996. Regulation of glutamate receptor subunit expression by drugs of abuse and stress: Common adaptations among cross-sensitizing agents. J. Neurosci. 16: 274-282.

Foltin, R.W. and Haney, M. 2000. Conditioned effects of environmental stimuli paired with smoked cocaine in humans. Psychopharmacology 149: 24-33.

Franklin, T.R., Acton, P.D., Maldjian, J.A., Gray, J.D., Croft, J.R., Dackis, C.A., O'Brien, C.P., and Childress, A.R. 2002. Decreased gray matter concentration in the insular, orbitofrontal, cingulate, and temporal cortices of cocaine patients. Biol. Psychiat. 51: 134-142.

Grant, S., London, E.D., Newlin, D.B., Villemagne, V.L., Liu, X., Contoreggi, C., Phillips, R.L., Kimes, A.S., and Margolin, A. 1996. Activation of memory circuits during cue-elicited cocaine craving. Proc. Natl. Acad. Sci. 93: 12040-12045.

Graziella De Montis, M., Co, C., Dworkin, S.I., and Smith, J.E. 1998. Modifications of dopamine D1 receptor complex in rats self-administering cocaine. Eur. J. Pharmacol. 362: 9-15.

Grimm, J.W., Shaham, Y., and Hope, B.T. 2002. Effect of cocaine and sucrose withdrawal period on extinction behavior, cue-induced reinstatement, and protein levels of the dopamine transporter and tyrosine hydroxylase in limbic and cortical areas in rats. Behav. Pharmacology 13: 379-388.

Hemby, S.E., Co, C., Koves, T.R., Smith, J.E., and Dworkin, S.I. 1997. Differences in extracellular dopamine concentrations in the nucleus accumbens during response-dependent and response-independent cocaine administration in the rat. Psychopharmacology 133: 7-16.

Heynen, A.J., Quinlan, E.M., Bae, D.C., and Bear, M.F. 2000. Bidirectional, activity-dependent regulation of glutamate receptors in the adult hippocampus in vivo. Neuron 28: 527-536.

Hutcheson, D.M., Everitt, B.J., Robbins, T.W., and Dickinson, A. 2001. The role of withdrawal in heroin addiction: Enhances reward or promotes avoidance? Nat. Neurosci. 4: 943-947.

Ito, R., Robbins, T.W., and Everitt, B.J. 2004. Differential control over cocaine-seeking behavior by nucleus accumbens core and shell. Nat. Neurosci. 7: 389-397.

Izquierdo, I., Souza, D.O., Carrasco, M.A., Dias, R.D., Perry, M.L. Eisinger, S., Elisabetsky, E., and Vendite, D.A. 1980. $\beta$-endorphin causes retrograde amnesia and is released from the rat brain by various forms of training and stimulation. Psychopharmacology 70: $173-177$.
Jaffe, J.H., Cascella, N.G., Kumor, K.M., and Sherer, M.A. 1989. Cocaine-induced cocaine craving. Psychopharmacology 97: 59-64.

Jentsch, J.D. and Taylor, J.R. 1999. Impulsivity resulting from frontostriatal dysfunction in drug abuse: Implications for the control of behavior by reward-related stimuli. Psychopharmacology 146: $373-390$

Johansson, A.K. and Hansen, S. 2000. Increased alcohol intake and behavioral disinhibition in rats with ventral striatal neuron loss. Physiol. Behav. 70: 453-463.

Kalivas, P.W. and Duffy, P. 1993. Time course of extracellular dopamine and behavioral sensitization to cocaine. I. Dopamine axon terminals. J. Neurosci. 13: 266-275.

Keys, A.S., Mark, G.P., Emre, N., and Meshul, C.K. 1998. Reduced glutamate immunolabeling in the nucleus accumbens following extended withdrawal from self-administered cocaine. Synapse 30: 393-401.

Koob, G.F. and Le Moal, M. 1997. Drug abuse: Hedonic homeostatic dysregulation. Science 278: 52-58.

. 2001. Drug addiction, dysregulation of reward, and allostasis Neuropsychopharmacology 24: 97-129.

Kuzmin, A. and Johansson, B. 1999. Expression of c-fos, NGFI-A and secretogranin II mRNA in brain regions during initiation of cocaine self-administration in mice. Eur. J. Neurosci. 11: 3694-3700.

Lago, J.A. and Kosten, T.R. 1994. Stimulant withdrawal. Addiction 89: $1477-1481$.

Loftis, J.M. and Janowsky, A. 2000. Regulation of NMDA receptor subunits and nitric oxide synthase expression during cocaine withdrawal. J. Neurochem. 75: 2040-2050.

London, E.D., Bonson, K.R., Ernst, M., and Grant, S. 1999. Brain imaging studies of cocaine abuse: Implications for medication development. Crit. Rev. Neurobiol. 13: 227-242.

Lowry, O.H., Rosenbrough, N.J., Farr, A.L., and Randall, R.J. 1951. Protein measurement with the folin phenol reagent. J. Biol. Chem. 193: $265-275$.

Lu, W. and Wolf, M.E. 1999. Repeated amphetamine administration alters AMPA receptor subunit expression in rat nucleus accumbens and medial prefrontal cortex. Synapse 32: 119-131.

Lu, L., Grimm, J.W., Shaham, Y., and Hope, B.T. 2003. Molecular neuroadaptations in the accumbens and ventral tegmental area during the first 90 days of forced abstinence from cocaine self-administration in rats. J. Neurochem. 85: 1604-1613.

Malinow, R. and Malenka, R.C. 2002. AMPA receptor trafficking and synaptic plasticity. Ann. Rev. Neurosci. 25: 103-126.

Mark, G.P., Hajnal, A., Kinney, A.E., and Keys, A.S. 1999. Self-administration of cocaine increases the release of acetylcholine to a greater extent than response-independent cocaine in the nucleus accumbens of rats. Psychopharmacology 143: 47-53.

Markou, A. and Koob, G.F. 1991. Postcocaine anhedonia. An animal model of cocaine withdrawal. Neuropsychopharmacology 4: 17-26.

Mason, S.T. 1983. The neurochemistry and pharmacology of extinction behavior. Neurosci. Biobehav. Rev. 7: 325-347.

Masserano, J.M., Baker, I., Natsukari, N., and Wyatt, R.J. 1996. Chronic cocaine administration increases tyrosine hydroxylase activity in the ventral tegmental area through glutaminergic- and dopaminergic D2-receptor mechanisms. Neurosci. Lett. 217: 73-76.

McFarland, K., Lapish, C.C., and Kalivas, P.W. 2003. Prefrontal glutamate release into the core of the nucleus accumbens mediates cocaine-induced reinstatement of drug-seeking behavior. J. Neurosci. 23: 3531-3537.

McLaughlin, J. and See, R.E. 2003. Selective inactivation of the dorsomedial prefrontal cortex and the basolateral amygdala attenuates conditioned-cued reinstatement of extinguished cocaine-seeking behavior in rats. Psychopharmacology 168: 57-65.

Micco Jr., D.J., McEwen, B.S., and Shein, W. 1979. Modulation of behavioral inhibition in appetitive extinction following manipulation of adrenal steroids in rats: Implications for involvement of the hippocampus. J. Comp. Physiol. Psych. 93: 323-329.

Nestler, E.J. 2001. Molecular basis of long-term plasticity underlying addiction. Nat. Rev. Neurosci. 2: 119-128.

O'Brien, C.P., Childress, A.R., McLellan, T., and Ehrman, R. 1990. Integrating systemic cue exposure with standard treatment in recovering drug dependent patients. Addict. Behav. 15: 355-365.

O'Brien, R.J., Xu, D., Petralia, R.S., Steward, O., Huganir, R.L., and Worley, P. 1999. Synaptic clustering of AMPA receptors by the extracellular immediate-early gene product Narp. Neuron 23: 309-323.

Ongur, D. and Price, J.L. 2000. The organization of networks within the orbital and medial prefrontal cortex of rats, monkeys and humans. Cerebral Cortex 10: 206-219.

Ortiz, J., Fitzgerald, L.W., Charlton, M., Lane, S., Trevisan, L., Guitart, X., Shoemaker, W., Duman, R.S., and Nestler, E.J. 1995. Biochemical

\section{Learning \& Memory}

www.learnmem.org 
actions of chronic ethanol exposure in the mesolimbic dopamine system. Synapse 21: 289-298.

Park, W.K., Bari, A.A., Jey, A.R., Anderson, S.M., Spealman, R.D Rowlett, J.K., and Pierce, R.C. 2002. Cocaine administered into the medial prefrontal cortex reinstates cocaine-seeking behavior by increasing AMPA receptor-mediated glutamate transmission in the nucleus accumbens. J. Neurosci. 22: 2916-2925.

Passafaro, M., Piech, V., and Sheng, M. 2001. Subunit-specific tempora and spatial patterns of AMPA receptor exocytosis in hippocampal neurons. Nat. Neurosci. 4: 917-926.

Pettit, H.O., Ettenberg, A., Bloom, F.E., and Koob, G.F. 1984. Destruction of dopamine in the nucleus accumbens selectively attenuates cocaine but not heroin self-administration in rats. Psychopharmacology 84: 167-173.

Porrino, L.J., Lyons, D., Miller, M.D., Smith, H.R., Friedman, D.P., Daunais, J.B., and Nader, M.A. 2002. Metabolic mapping of the effects of cocaine during the initial phases of self-administration in the nonhuman primate. J. Neurosci. 22: 7687-7694.

Pothos, E., Rada, P., Mark, G.P., and Hoebel, B.G. 1991. Dopamine microdialysis in the nucleus accumbens during acute and chronic morphine, naloxone-precipitated withdrawal and clonidine treatment. Brain Res. 566: 348-350.

Quinlan, E.M., Philpot, B.D., Huganir, R.L., and Bear, M.F. 1999. Rapid experience-dependent expression of synaptic NMDA receptors in visual cortex in vivo. Nat. Neurosci. 2: 352-357.

Robbins, S.J., Ehrman, R.N., Childress, A.R., and O'Brien, C.P. 1997. Relationships among physiological and self-report responses produced by cocaine-related cues. Addict. Behav. 22: 157-167.

Roberts, D.C.S. and Koob, G.F. 1980. Extinction and recovery of cocaine self-administration following 6-hydroxydopamine lesions of the nucleus accumbens. Pharmacol. Biochem. Behav. 12: 781-787.

Robinson, T.E., Gorny, G., Mitton, E., and Kolb, B. 2001. Cocaine self-administration alters the morphology of dendrites and dendritic spines in the nucleus accumbens and neocortex. Synapse 39: 257-266.

Rossetti, Z.L., Hmaidan, Y., and Gessa, G.L. 1992. Marked inhibition of mesolimbic dopamine release: A common feature of ethanol, morphine, cocaine and amphetamine abstinence in rats. Eur. J. Pharmacol. 221: 227-234.

Roth-Deri, I., Zangen, A., Aleli, M., Goelman, R.G., Pelled, G., Nakash, R., Gispan-Herman, I., Green, T., Shaham, Y. and Yadid, G. 2003. Effect of experimenter-delivered and self-administered cocaine on extracellular $\beta$-endorphin levels in the nucleus accumbens. $J$. Neurochem. 84: 930-938.

Scherer, A., Krause, A., Walker, J.R., Sutton, S.E., Seron, D., Raulf, F., and Cooke, M.P. 2003. Optimized protocol for linear RNA amplification and application to gene expression profiling of human renal biopsies. Biotechniques 34: 546-550, 552-544, 556.

Schmidt, E.F., Sutton, M.A., Schad, C.A., Karanian, D.A., Brodkin, E.S., and Self, D.W. 2001. Extinction training regulates tyrosine hydroxylase during withdrawal from cocaine self-administration. $J$. Neurosci. 21: RC137.

Self, D.W. and Nestler, E.J. 1995. Molecular mechanisms of drug reinforcement and addiction. Ann. Rev. Neurosci. 18: 463-495. . 1998. Relapse to drug seeking: Neural and molecular mechanisms. Drug Alcohol Depend. 51: 49-60.

Self, D.W., McClenahan, A.W., Beitner-Johnson, D., Terwilliger, R.Z. and Nestler, E.J. 1995. Biochemical adaptations in the mesolimbic dopamine system in response to heroin self-administration. Synapse 21: $312-318$

Shi, S.-H., Hayashi, Y., Esteban, J.A., and Malinow, R. 2001 Subunit-specific rules governing AMPA receptor trafficking to synapses in hippocampal pyramidal neurons. Cell 105: 331-343.

Simmons, D.L., Hoppenot, R., Frantz, K., Walker, J.W., Feinberg, A. Edwards, S.L., and Self, D.W. 2002. Long-term changes in nucleus accumbens gene expression following chronic cocaine self-administration. Soc. Neurosci. Abstr. 28: 500-514.

Sinha, R., Catapano, D., and O'Malley, S. 1999. Stress induced craving and stress response in cocaine dependent individuals. Psychopharmacology 142: 343-351.

Sorg, B.A., Chen, S.-Y., and Kalivas, P.W. 1993. Time course of tyrosine hydroxylase expression after behavioral sensitization to cocaine. $J$. Phamacol. Exp. Ther. 266: 424-430.

Stewart, J. 2003. Stress and relapse to drug seeking: Studies in laboratory animals shed light on mechanisms and sources of long-term vulnerability. Am. J. Addict. 12: 1-17.

Sutton, M.A., Schmidt, E.F., Choi, K.-H., Schad, C.A., Whisler, K., Simmons, D., Karanian, D.A., Monteggia, L.M., Neve, R.L., and Self, D.W. 2003. Extinction-induced up-regulation in AMPA receptors reduces cocaine-seeking behaviour. Nature 421: 70-75.

Takahashi, T., Svoboda, K., and Malinow, R. 2003. Experience strengthening transmission by driving AMPA receptors into synapses. Science 299: 1585-1588.

Tang, W., Wesley, M., Freeman, W.M., Liang, B., and Hemby, S.E. 2004. Alterations in ionotropic glutamate receptor subunits during binge cocaine self-administration and withdrawal in rats. J. Neurochem. 89: 1021-1033.

Thomas, M., Beurrier, C., Bonci, A., and Malenka, R. 2001. Long-term depression in the nucleus accumbens: A neural correlate of behavioral sensitization to cocaine. Nat. Neurosci. 4: 1217-1223.

Todtenkopf, M.S., De Leon, K.R., and Stellar, J.R. 2000. Repeated cocaine treatment alters tyrosine hydroxylase in the rat nucleus accumbens. Brain Res. Bull. 52: 407-411.

Trulson, M.E., Joe, J.C., Babb, S., and Raese, J.D. 1987. Chronic cocaine administration depletes tyrosine hydroxylase immunoreactivity in the meso-limbic dopamine system in rat brain: Quantitative light microscopic studies. Brain. Res. Bull. 19: 39-45.

Volkow, N.D. and Fowler, J.S. 2000. Addiction, a disease of compulsion and drive: Involvement of the orbitofrontal cortex. Cerebral Cortex 10: $318-325$.

Volkow, N.D., Hitzemann, R., Wang, G.J., Fowler, J.S., Wolf, A.P., Dewey, S.L., and Handlesman, L. 1992. Long-term frontal brain metabolic changes in cocaine abusers. Synapse 11: 184-190.

Vrana, S.L., Vrana, K.E., Koves, T.R., Smith, J.E., and Dworkin, S.I. 1993. Chronic cocaine administration increases CNS tyrosine hydroxylase enzyme activity and mRNA levels and tryptophan hydroxylase enzyme activity levels. J. Neurochem. 61: 2262-2268.

Watt, A.J., Sjostom, P.J., Hauser, M., Nelson, S.B., and Turrigiano, G.G. 2004. A proportional but slower NMDA potentiation follows AMPA potentiation in LTP. Nat. Neurosci. 7: 518-524.

Weiss, F., Markou, A., Lorang, M.T., and Koob, G.F. 1992. Basal extracellular dopamine levels in the nucleus accumbens are decreased during cocaine withdrawal after unlimited-access self-administration. Brain Res. 593: 314-318.

Weissenborn, R., Robbins, T.W., and Everitt, B.J. 1997. Effects of medial prefrontal or anterior cingulate cortex lesions on responding for cocaine under fixed-ratio and second-order schedules of reinforcement in rats. Psychopharmacology 134: 242-257.

White, F.J. and Kalivas, P.W. 1998. Neuroadaptations involved in amphetamine and cocaine addiction. Drug Alcohol Depend. 51: $141-153$.

White, F.J., Hu, X.T., Zhang, X.F., and Wolf, M.E. 1995. Repeated administration of cocaine or amphetamine alters neuronal responses to glutamate in the mesoaccumbens dopamine system. J. Pharmacol. Exp. Ther. 273: 445-454.

Wilson, J.M., Nobrega, J.N., Corrigall, W.A., Coen, K.M., Shannak, K., and Kish, S.J. 1994. Amygdala dopamine levels are markedly elevated after self- but not passive-administration of cocaine. Brain Res. 668: 39-45.

Wise, R.A. 1998. Drug-activation of brain reward pathways. Drug Alcohol Depend. 51: 13-22.

Wright, C.I. and Groenewegen, H.J. 1995. Patterns of convergence and segregation in the medial nucleus accumbens of the rat: Relationships of prefrontal cortical, midline thalamic, and basal amygdaloid afferents. J. Comp. Neurol. 361: 383-403.

Yao, W.D., Gainetdinov, R.R., Arbuckle, M.I., Sotnikova, T.D., Cyr, M., Beaulieu, J.M., Torres, G.E., Grant, S.G., and Caron, M.G. 2004 Identification of PSD-95 as a regulator of dopamine-mediated synaptic and behavioral plasticity. Neuron 41: 625-638.

Zangen, A. and Shalev, U. 2003. Nucleus accumbens $\beta$-endorphin levels are not elevated by brain stimulation reward but do increase with extinction. Eur. J. Neurosci. 17: 1067-1072

Zito, K.A., Vickers, G., and Roberts, D.C.S. 1985. Disruption of cocaine and heroin self-administration following kainic acid lesions of the nucleus accumbens. Pharmacol. Biochem. Behav. 23: 1029-1036.

Received May 7, 2004; accepted in revised form August 10, 2004. 


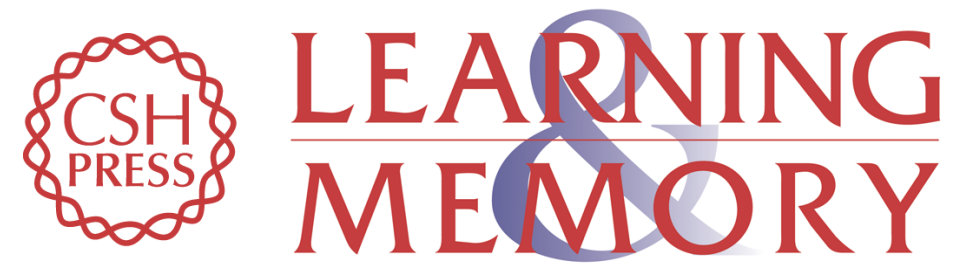

\section{Extinction Training Regulates Neuroadaptive Responses to Withdrawal from Chronic Cocaine Self-Administration}

David W. Self, Kwang-Ho Choi, Diana Simmons, et al.

Learn. Mem. 2004, 11:

Access the most recent version at doi:10.1101//m.81404

References This article cites 102 articles, 16 of which can be accessed free at: http://learnmem.cshlp.org/content/11/5/648.full.html\#ref-list-1

License

Email Alerting

Receive free email alerts when new articles cite this article - sign up in the box at the Service top right corner of the article or click here. 